\section{GENRE}

en séries
Genre en séries

Cinéma, télévision, médias

5 | 2017

Masculinités imag(in)les 2

\title{
Patriarchal Masculinity's Seductive Valorization and Attraction : Post Second-Wave Gender Politics Renegotiated on Scandal (ABC, 2011-) and The Good Wife (CBS, 2009-2016)
}

\section{Anne Sweet Fédé}

\section{OpenEdition}

\section{Journals}

Electronic version

URL: http://journals.openedition.org/ges/863

DOI: $10.4000 /$ ges.863

ISSN: 2431-6563

\section{Publisher}

Presses universitaires de Bordeaux

Electronic reference

Anne Sweet Fédé, "Patriarchal Masculinity's Seductive Valorization and Attraction : Post Second-Wave Gender Politics Renegotiated on Scandal (ABC, 2011- ) and The Good Wife (CBS, 2009-2016)", Genre en séries [Online], 5 | 2017, Online since 01 June 2017, connection on 22 March 2021. URL: http:// journals.openedition.org/ges/863; DOl: https://doi.org/10.4000/ges.863

This text was automatically generated on 22 March 2021.

\section{(i) $\$$

La revue Genre en séries est mise à disposition selon les termes de la Licence Creative Commons Attribution - Pas d'Utilisation Commerciale - Pas de Modification 4.0 International. 


\title{
Patriarchal Masculinity's Seductive Valorization and Attraction : Post Second-Wave Gender Politics Renegotiated on Scandal (ABC, 2011- ) and The Good Wife (CBS, 2009-2016)
}

\author{
Anne Sweet Fédé
}

1 The Good Wife (CBS, 2009-2016) and Scandal (ABC, 2011-) appear on the surface to be showcases for two of TV's strongest most empowered TV series' heroines to date, Alicia Florrick, a lawyer, and Olivia Pope, a crisis manager, respectively. But a Time Magazine article points out that many recent TV heroines have one fatal "flaw», or " Kyptonite ", which is that « empowered women are making terrible decisions because of men » (Dockterman, 2013).

2 Moreover, in some recent women-centered series, there seems to be a new dynamic: the seeming reaffirmation of the patriarchal male's importance, position and attractiveness. It is his very power that empowers and attracts the female heroines, while also potentially undermining them through their association with, and support of, men who are often cruel and deceitful. This can be seen in Olivia Pope's relationship with her main love interest, Fitzgerald («Fitz») Grant, the President of the United States, and Alicia Florrick's relationship with her husband, Peter Florrick, State's Attorney, and then Governor of Illinois. The co-dependency and reconciliation of empowered women with patriarchal men in Scandal and The Good Wife seems to be a renegotiation of masculine and feminine identities and gender roles. But does it represent a backlash? Or are these murkier, less idealistic, and complicated post second-wave representations of sex and gender politics? Is there a new dynamic at work? 


\section{Negotiating The Discourses of the « Natural » Gender}

While masculinity is often considered to be the «invisible " gender, Chris Holmlund, notably, underlines, that masculinity is as much a "performance » or masquerade as femininity, and this "performance» can involve "multiple» levels and layers (Holmlund, 1993 : 215). Sherrie Inness affirms, " Masculinity, in short, is a set of signs that connote maleness within a given cultural moment, and masculinity is as fluid and as changing as the society defining it (Inness, $1997: 185$ ). Amanda Lotz notes the perceived « naturalness » of the male gender could be one factor that explains why, for a long time, few masculinity studies were done specifically about TV, and why much less research has been conducted in this area when compared to the amount that has been done on issues of women on TV, or even masculinity in the cinema (Lotz, 2014: 9). She writes :

Perhaps few have considered the history of male portrayal because so many characteristics seemed unexceptional due to their consistency with expectations and because no activist movement has pushed a societal reexamination of men's gender identity in the manner that occurred for women as a component of secondwave feminism. Male characters performed their identity in expected ways that were perceived as «natural » and drew little attention, indicating the strength of these constructs (Lotz, 2014: 9).

Moreover, the institutional and production constraints of the primetime television medium during the network age - such as attempting to appeal to as many people as possible, which meant trying hard not to shock or offend - led to a certain banality of masculine representations, until the development of cable channels in the 90s that targeted specific niche markets was the catalyst for developing more diversified content (Lotz, $2014: 1-18$ ).

While TV series and their characters are works of fiction, they can nevertheless have a real-life impact on their viewers, and understanding questions of representation and the messages conveyed by such media products are thus essential. Julie D'Acci notably underlines that TV can be influential in an audience's conceptualization of gender roles and dynamics, and there are «negotiating discourses » among institutions, mass media and audiences. She maintains that

social power is produced and exercised in myriad discrete instances; that power over meanings - its many shifts and struggles - may be analyzed and understood; that gender (like all aspects of the human subject) is not something acquired and settled once and for all at birth or shortly thereafter but is constantly in process, continually being shaped, enacted and reconfigured; and that television (one of our culture's most productive technologies for generating images of masculinity and femininity) is a major participant in shaping the gender of its audience (D'Acci, 1994 : 3).

6 Thus viewers' definitions and perceptions of gender are being negotiated through watching TV series. Notions of gender roles - of men and masculinity, and of women, femininity and feminism - are constantly being reconceptualized both by institutions and viewers.

Yet these relationships are complex. Michel Foucault writes, «Where there is power, there is resistance » (Foucault 1990 [1978] : 95). Applying Foucault's ideas to a TV series in her study of Charmed (WB, 1998-2006), Catriona Miller maintains that TV series' discourses can be « an instrument of power and an effect of power » but also a « point 
of resistance " (Miller, 2007 : 78). A TV series can thus serve as « a site of negotiation " for competing and interwoven power discourses (Miller, $2007: 78$ ).

Incorporating issues of power and contestation into her study of male characters on cable TV series, Lotz considers TV representations of masculinity in terms of either « patriarchal » or « feminist » masculinities. She writes, « Patriarchal ideologies are the functional opposite of feminist ideologies in that patriarchy seeks to allow special privileges and authority for men - and particularly, straight, white, affluent or educated men - and to reinforce men's dominant gender status in society " (Lotz, 2014 : 34). Thus, rather than examining gender representations in TV series like The Good Wife and Scandal as either "progressive " or "regressive ", it is important to analyze the intricate negotiation of the push and pull of competing discourses of dominant patriarchal masculinities and feminist heroines. These discourses are a product of societal values, and through the medium's omnipresence have the power to influence and renegotiate social discourses around gender roles.

In order to examine these gender discourses from a multi-dimensional perspective, a media studies' approach to TV series' analysis that involves examining both intrinsic and extrinsic aspects of a series is applicable. In a study of the TV industry and femaleoriented content, Lotz notably employs a "subcategory" of media studies called «feminist television criticism», as it was used by Lynn Spigel, Julie D'Acci, and Charlotte Brundson in their book Feminist Television Criticism (Lotz, 2006; Brundson, D'Acci and Spigel, 1997). Lotz defines this « synthetic approach » as a

blending of various contributions of feminism, cultural studies, film studies and some mass communications perspectives. Feminist television criticism primarily focuses on texts within a critical historical, cultural and industrial context and includes an awareness of multiple sites of investigation (institutions, texts and audiences), even if these areas are not specifically incorporated within an individual work. (Lotz, $2006: 18$ )

With its emphasis on "multiple sites of investigation", this feminist media studies framework will be applied in the analysis of the negotiating discourses of the gender in The Good Wife and Scandal. Extratextual series' discourses will be examined by looking at the series' background, production context, and audiences. While a full reception study of the public is outside the breadth and scope of this study, reception will nevertheless be examined through a non-exhaustive look at a selection of fan and press discourses. Intratexual discourses will be examined through a semiotic analysis of some of the feminist and patriarchal discourses at issue within the series themselves.

\section{Series' Production Context, Audiences, and Background}

11 Both The Good Wife and Scandal are commercially and culturally successful, often averaging more than eight million viewers per episode, and both have been nominated for, and have won, multiple awards, including Emmys, Screen Actors' Guild Awards and Golden Globes. Episodes last approximately 45 minutes. They are broadcast in one-hour timeslots, with the other 15 minutes being consecrated to advertising. Both series often feature a case-of-the week, in addition to the ongoing narrative of plots involving the heroines' personal lives and professional projects. Both are political dramas, even if The Good Wife is also a bit of a hybrid. It could be also considered a legal drama, yet Alicia's 
husband's political ambitions (and later her own) feature heavily in the narrative and are essential to character development. Adweek notes that the political drama is a genre that has reformatted to tailor itself to a more female viewership, and cites Scandal as part of a trend in the TV industry to create and promote content designed to engage female viewers : «Part of the reason so much is available to women now as opposed to a decade ago is simply that as viewership has fragmented still further, men have become less important to advertisers who want to reach viewers with control over disposable income" (Thielman, 2014). The article further cites women's purchasing power - the fact that they are often in control of the family's spending - and that the recession recovery has been better to women in terms of employment as reasons why female viewership has become increasingly important to advertisers and media producers (Thielman, 2014). The Good Wife and Scandal - which feature beautiful, educated, successful and fashionably dressed lead heroines - present an aspirational version of empowered womanhood popular with both viewers and advertisers.

Scandal began on $\mathrm{ABC}$ in 2012. At the time of this study, it has five completed seasons and 90 episodes. Shonda Rhimes, who is well known for her work on Grey's Anatomy (ABC, 2005-), is the creator and showrunner. In the 2014-2015 season, it was the most popular Twitter series with fans (Kissel, 2015). It is notable that the character of Olivia Pope is based on former White House deputy press secretary Judy Smith, who is also a crisis manager, and who has served as co-executive producer of the series (Simpson, 2012). Scandal is more popular with female viewers than male viewers, and is especially popular with African-American viewers in general, and more especially AfricanAmerican women in particular (Barr, 2015 ; Prince, 2014 ; Vega, 2013). A New York Times article notes that Olivia Pope (played by Kerry Washington) was the first AfricanAmerican lead heroine in a series since Get Christie Love! (ABC, 1974-1975) and that this representation may indicate the ushering in of « a new era of postracial television, in which cast members are ethnically diverse but are not defined by their race or ethnicity " (Vega, 2013). Showrunner Shonda Rhimes believes that TV representations have power and in a speech at the 2016 International Emmy Awards she encouraged further diversity, saying of the television medium :

It's the most powerful source of communication in the world: We sit with you in your homes, you spend more hours with many of my characters than you do with members of you own family [...] That comes with an enormous responsibility, and I take it very seriously. Words have power. TV has power. My pen has power » (Lee, 2016).

She wields this power not only in Scandal, but in Grey's Anatomy and How to Get Away with Murder (ABC, 2014-), two of her other series that are broadcast on the same evening as Scandal. Each features a wide range of characters of different ethnic and sexual identities. The three programs together form a ratings juggernaut on Thursday nights called \#TGIT (or " Thank God It's Thursday »).

The Good Wife, which began on CBS in 2009, has 156 episodes and it has just completed its seventh and final season. The Good Wife's creators and showrunners, a husband and wife, Robert and Michelle King, crafted it based on real-life political scandals where wives stood by their husbands (NPR Staff, 2015). The show was broadcast first on Tuesday nights, and then on Sunday nights, where it drew less viewers but nevertheless attracted « upscale advertisers » like Cartier. It was thus considered « valuable network commodity ", according to a Deadline article in which CBS Entertainment president Nina Tassler commented, "The audience that watches on Sunday night is upscale, very 
female and very engaged» (Haitman, 2012). The actress who played Alicia Florrick on The Good Wife, Julianna Margulies, was also a producer of the show, which meant she had input into her own character's representation. Before The Good Wife, she had been well known in the late 90s for her Emmy-winning portrayal of the much put-upon nurse Carol Hathaway, who was part of the diverse ensemble cast of the successful, mainstream medical drama $E R$ (NBC, 1994-2009) ${ }^{1}$.

Both Scandal and The Good Wife are exceptions in the industry to have women in charge and to benefit from significant female input. According to research conducted by San Diego State University's Center for the Study of Women in Television and Film, in the 2013-2014 primetime TV season, women made up only 43 percent of producers, 25 percent of writers, 23 percent of executive producers, 20 percent of creators, 17 percent of editors, 13 percent of directors, and two percent of directors of photography that were involved in the production of primetime television (Gibson, 2014 ; Lauzen, $2014)^{2}$. Furthermore, women only made up 42 percent of characters with speaking parts as well as 42 percent of main characters. Moreover, on cable, where high-profile women-created and women-centered series Orange is the New Black (Netflix, 2013-) and Girls (HBO, 2012-) reign, parity in key areas of production has also not yet been achieved (Gibson, 2014 ; Lauzen, 2014).

The amount of women involved in television production affects the representations of women on the screen. A Time Magazine article notes, « According to the numbers, when a program had at least one woman writer on staff, 'females accounted for $46 \%$ of all characters'. Yet the number of female characters dropped to $38 \%$ when there were no women writers on staff » (Gibson, 2014). Thus, Scandal and The Good Wife are unique in that women (or in the latter case a husband-wife team) are in charge, and it is therefore surely not incidental that the characters of Olivia and Alicia are so rich and complex and that the actresses who play them (Kerry Washington and Julianna Margulies respectively) have been nominated for and won multiple awards for their portrayals ${ }^{3}$.

In both series, questions of power and gender dynamics are tied up in the fact that the series are about actual politics, with many plotlines inspired by real news and political situations ${ }^{4}$. In fact, both shows begin with a sex scandal that could harken back to the Bill Clinton/Gennifer Flowers and/or Bill Clinton/Monica Lewinsky scandals from the 90s. Scandal begins with Olivia Pope's attempting to prevent a woman, Amanda Tanner, from revealing her affair with the President. In the beginning of The Good Wife, Alicia Florrick's husband (at the time a former State's Attorney) is in jail for corruption and his affair with a prostitute has also been exposed. Whether the central characters be Republicans in the case of Scandal, or Democrats in the case of The Good Wife, politics and politicians are portrayed as corrupt. Scandal's Olivia Pope, who "wears the white hat ", is a PR crusader for good (when not involved in helping the President) along with her staff the "gladiators »; Alicia Florrick, «the good wife » (also called "Saint Alicia » by the press), while not always particularly, "good», stands out as one of the least amoral characters amidst political corruption and an often hostile work environment. Both characters are very complex, and less-than-perfect, but their "goodness" contrasts starkly with work and political environments pervaded by backstabbing, criminality, and dishonesty, and thus serves as a critique of contemporary political culture. While society often still gives women the message that they should be «nice " and "good» (or in other words " morally virtuous" and " passive»), the heroines are not particularly either. They can be just as ambitious, uncompromising, and even 
unethical as some of the male (and female) characters that surround them, and it is notable that the plots feature female antagonists. As protagonists - and points of identification for the viewers - Alicia and Olivia are positioned as sympathetic characters, and they remain slightly less «bad», and in contrast a bit «nicer», than the others. Thus, these representations embody a post-sexual revolution version of "good" women in popular culture, who do not have to be sweet, virginal, and pure like characters played by Doris Day in movies the $60 \mathrm{~s}$ - but who reflect the acceptance of « good» women who are strong, assertive, and sexually active.

\section{Post-Second Wave Feminist Heroines}

Scandal and The Good Wife can both be positioned as "feminist " series, and feminist discourses are being negotiated both intratextually and extratextually. Audiences read the series as «feminist» and extoll and/or critique the potentially feminist messages therein. This can be seen through fan and media discourses on websites, on social media and in multiple press articles on the subject. For instance, the site Reddit featured a fan thread about The Good Wife entitled «A fond feminist farewell to Ms. Florrick» and one about Scandal entitled « Misogyny disguised as feminism? $»^{5}$. Social media and fan websites are also platforms for feminist messages related to the shows. For instance, the Twitter site «Scandal Fan ABC » featured a \#Stand with PP (Planned Parenthood) campaign that touted the fact that Kerry Washington had tweeted her support ${ }^{6}$. Articles abound on the series' potentially feminist content and messages in the press. For example, The Huffington Post article, «The Conversation 'The Good Wife' Wants Women To Have ", analyzes discourses about work/life balance. A Salon article, "Lean out: The underhanded feminism of 'The Good Wife', critiques a certain lack of sisterhood in the series (Drumming, 2014). A New York Post article asks, "Is 'Scandal' the most feminist show on TV?» (Putnam, 2014). A New Republic article called «A MidSeason Assessment of 'Scandal's' New Feminist Speechifying " discusses deliberate feminist messages inserted into the series (Breger, 2014). A Buzzfeed article entitled « 9 of The Most Powerful Feminist Characters Currently On TV » lists a character from Scandal and one from The Good Wife, Mellie Grant and Diane Lockhart respectively (Pokedoff, 2014).

If both series are thus perceived and received as "feminist » extratextually, it is certainly in part because their strong, career-oriented lead heroines embody certain ideals of the second-wave of the women's liberation movement. Karin Beeler defines the second wave thus: "Second-wave feminism, the movement of the 1960s to the 1980s, has been understood as a debate about equality, feminist activism, 'equal access to the workforce' and criticism of patriarchy " (Beeler, 2007 : 102-103). The 1990s saw the rise of "third wave feminism ", which Astrid Henry notes involves a generation of women who had "never lived in a world without the women's movement " and which was much more focused individual choices (such as whether to get married or not) than on collective political and social activism (Henry, 2006:66, 72). The ideals of the third wave are reflected, for example, in Sex and the City (HBO, 1998-2004), a successful women-centered TV series, about which Henry writes: «Sex and the City reflects an important - if limited - vision of female empowerment, a feminism that mirrors contemporary third wave attempts to celebrate women's power and women's sexuality, to create a world where one can be both feminist and sexual » (Henry, 2006:82). 

celebration of the female consumer, and Tasker and Negra note that "postfeminist culture " insists on the idea of "choice", something that is only reserved to more affluent women. They write, "Postfeminist culture works in part to incorporate, assume, or naturalize aspects of feminism; crucially, it also works to commodify feminism via the figure of the empowered woman consumer. Thus, postfeminist culture emphasizes educational and professional opportunities for women and girls; freedom of choice with respect to work » (Tasker and Negra, $2007: 2$ ).

However, in her study of recent cable TV series' male characters, Lotz rejects both the terms «third-wave feminism», and "postfeminism» as "too fraught with contradictory meanings to be useful ». She writes, "The challenge to patriarchal masculinities evident in many aspects of the series is more clearly an outcome of second-wave activism - albeit long in fruition - than a result of more nascent feminist generations or their endeavors, which makes 'post second-wave' my preferred terminology » (Lotz, $2014: 23)$. In fact, she analyzes men in terms of " post second-wave masculinities » (Lotz, $2014: 23$ ). Thus the heroines of contemporary fictions can also be discussed in terms of "post second-wave femininities " as many of the changes in women's lives and representations surely have their origins in the second wave. The situations of the heroines of Scandal and The Good Wife as sexually liberated career women illustrate the social progress begot by the second-wave feminist movement, even if its goals are not perfectly realized, and are the result of a gradual evolution in societal values. Thus the terminology "post-second wave " is applicable for studying questions of both masculinity and femininity.

In fact, both The Good Wife and Scandal deliberately and openly insert feminist discourses into their plots, and thus position themselves as fare for empowered and empowering audiences. For example, in the episode, Randy, Red, Superfreak and Julia [S04xE01], Olivia gives a televised speech denouncing sexual harassment and poor pay for women, notably the fact that women only earn « 77 cents for every male dollar », a statistic that was previously famously cited by real-life US President Barack Obama in his 2013 and 2014 State of the Union addresses (Kessler, 2014). In the episode Baby It's Cold Outside [S05xE09], Scandal tackles the thorny subject of abortion. Not only does Olivia undergo an abortion (even though the word is never said at the time), but the President's ex-wife Mellie Grant (as a US Senator) filibusters to block a bill that would defund Planned Parenthood. A Huffington Post article notes that this was "a rippedfrom-the-headlines move that had Twitter cheering» and that it inscribed itself in Shonda Rhimes' use of "Scandal as a vehicle to talk about real-life social justice issues " (Samakow, 2015). An intratextual and extratexual feminist episode features Girls creator and actress, Lena Dunham, who was named voice of a generation for her «realistic " portrayal of twenty-somethings and who is very outspoken on issues of women's rights and questions of body image. In It's Good to be Kink [S04xE16], she plays Susan Thomas (aka "Kinky Sue»), a woman who picks up men on a web site called " Land of Kink », has « kinky » sex with them, and hopes to recount it all in a memoire that would expose the sex secrets of important patriarchal men. When Olivia asks Susan if she worries what people will think of her, she replies,

I'm not ashamed. This is my life, my body, my story to sell or tell or... anyway, it's all I've got now. Okay? So, go ahead and call me a whore. Everyone who writes a memoir is a whore. You can also call me an author, an artist, a businesswoman. You can call me smart, and pretty soon, you can call me successful. 

balance and the difficulties of going back to work after taking time off to have children. When Peter is arrested for corruption she must reenter the workforce after over a decade of being at home, and must start as a first-year associate, a post from which she eventually rises to become head of her own firm before unsuccessfully running for State's Attorney. In the episode A Few Words [S05xE14], Alicia is asked to prepare a keynote speech for an important conference of legal professionals about her trajectory from « opt-out mom » (a high-potential working woman who steps off the career track to be a mother) to partner in a law firm. In flashbacks it shows her struggle to find employment after "opting out» and how she imagines her mother-in-law (a «traditional ", pre-second wave woman) calling her a "whore" when she wears a pretty dress in attempt to charm Will Gardner (her ex-college boyfriend at the time) into giving her a job. Her husband's imprisonment has left her without enough money to live on, and she has two children to support, so the viewer is positioned to feel compassion for her desperation to find paid work rather than to scorn her behavior. While Alicia is clever and possesses a law degree from Georgetown University, she must resort to flirting with a patriarchal male to find employment - no one else will hire her. Outside of the flashbacks, Alicia's male associates encourage her to use words like «empowerment» and "feminism» in her speech about her successes in order to attract a prominent female lawyer to work at their firm, which is a bit of a wink to the viewer that the episode is deliberately telling a feminist tale. Yet watching Alicia in the flashbacks, there is a sense of the disempowerment she felt as she tried to navigate the fact that her «choice" had been taken away from her, exposing the successes of the second wave as being imperfectly realized and creating audience awareness of an important social issue. Like Scandal, The Good Wife also associates itself with an extratexual feminist figure in the form of second-wave activist Gloria Steinem. Playing herself in the episode Dear God [S06xE03] where she is introduced as a "feminist icon ", Steinem encourages Alicia to run for the office of State's Attorney, saying, "We need more good women to run ». Like Scandal, The Good Wife thus deliberately position itself as « feminist » both intra and extratexually.

The main characters of Alicia and Olivia are not the only representations of strong women on their respective series. Abby_Whelan, Olivia's best friend, becomes the White House's spokesperson and then its chief of staff; Quinn Perkins, Olivia's associate, is tough, violent and smart; and there are two female vice presidents (Susan Ross and Sally Langston), and two female chiefs of staff (Elizabeth North, as well as Abby). On the surface, the least empowered of the female characters is the President's wife (and later ex-wife), Mellie Grant - at least in the first few seasons. Mellie must play the perfect housewife in her 60s-style suits and pearls, yet is every bit as intelligent as her husband. She is also scheming and conniving, even working with Olivia to further Fitz's ambitions. She eventually becomes Senator of Virginia in her own right, and then runs for president. Mellie is the character that most embodies gender as performance, as she plays the role of the First Lady to perfection, while in her private space being a very different person. She plays the role of a good mother, while in reality, spending very little time with her children, and she also plays the role of the perfect spouse when it often appears as if she loves the power of her position much more than Fitz. On The 
Good Wife, two notable empowered female characters are Kalinda Sharma, an investigator who is extremely violent, very clever, sexually aggressive and also bisexual, and Diane Lockhart, an older woman who is Alicia's boss, and who-when Will Gardner dies-becomes the head of the firm. Diane is positioned openly as no-holdsbarred liberal who is a fan of Hilary Clinton. She represents an important and atypical positive positioning of a woman from the second wave as competent, respectable, intelligent, attractive, calm and powerful, without being portrayed as silly, catty, petty, superficial, or shrill. She survives numerous attacks on her power by the aggressive men around her. The fact that there are a variety of empowered women working in environments filled with patriarchal, even hostile men, shows the process of contestation of patriarchal discourses, yet physically speaking, all the women conform to standards of beauty and femininity, at least on the surface. There is not one truly "butch », or gender fluid woman among them in appearance - perhaps to maintain the aspirational beauty standards that attract the empowered female viewer/consumers so desired by network powers-that-be - yet the representations of sexual politics are innovative in other ways.

\section{Polyamorous Post-Second Wave Sexual Politics}

Both Scandal and The Good Wife show changing sexual mores and innovative sexual dynamics and politics that demonstrate feminism's success in giving women greater sexual freedom and legitimizing their right to sexual desire and fulfillment. Throughout most of both series, the lead heroines are involved in three-way love affairs with patriarchal men. Olivia is in love with Fitz while also dating Jake Ballard, a navy captain and black ops' operative for a secret governmental espionage organization called B613; Alicia, is married to Peter, and alternates in feeling warm or angry towards him, but also has feelings for her boss, Will Gardner, with whom she carries out a brief affair and for whom she has feelings throughout his tenure on the series. All of these men represent to a certain extent patriarchal masculinity. They maintain positions of power. They are all stoic, aggressive and ambitious, even if the secondary love interests, Will and Jake, are somewhat more sensitive, caring and certainly less powerful ${ }^{7}$.

A notable aspect of the murky and subversive sexual politics of The Good Wife, and Scandal is that extra-marital sex is normalized and the viewer is positioned to be sympathetic to the characters caught up in love triangles. Yet both Alicia and Olivia are implicated in what is technically adultery. Alicia not only sleeps with Will, but also her campaign manager Johnny Elfman and then her firm's investigator Jason Crouse, while still married to Peter; Olivia causes Fitz to cheat on Mellie, and things get even more complex when one considers that Mellie continues to sleep with her husband even though she is aware (and he knows she is aware) that his true love is Olivia. Mellie also cheats on Fitz with Vice-President Andrew Nichols. Both Alicia and Olivia love patriarchal men but resist being dominated by the lovers and completely under their control through polyamory: They belong to no one man individually or in particular. Their polyamorous relationships put them on an equal footing with powerful men for whom sleeping around can be considered as one of the privileges and perks of success. In literature, TV and film, adulteresses and mistresses have often been depicted as «bad women » and «sluts", who were often even punished in the narrative and met a 
bad end. In The Good Wife and Scandal, the heroines do not seem to suffer any particularly tragic ill consequences a result of their affairs, and they remain positioned as sympathetic characters.

The shows represent changing social mores, and sexual freedom in other ways as well. Both shows feature non-heterosexual characters in the main cast. In The Good Wife, Kalinda has affairs with both men and women. In Scandal, White House Chief of Staff Cyrus Beene is an openly gay man who is first depicted as married and later as having a relationship with a male prostitute. Moreover, women positioned as heroines are allowed to express their sexuality in unconventional ways. Quinn has violent relationships with the men in her life, sleeping notably with Huck, one of Olivia's associates, who once tied her up and tortured her by extracting a tooth. Kalinda equally mixes sex and violence with her husband Nick in scenes that were so extreme that they were unpopular with viewers (Harnick, 2012). In the aforementioned episode, It's Good to be Kink [S04xE16], « Kinky Sue » seems to inspire Abby and Olivia's sexuality in new ways. In the last scene with Abby and her boyfriend Leo Bergman (who was one of Sue's partners, as well as Abby's ex-boyfriend Attorney General David Rosen), she asks him to "get the butter" from the kitchen to use during their amorous relations in the bedroom. Olivia, who at the time is on the outs with both Fitz and Jake, picks up a onenight stand at a bar. At the end of the episode, he and she are seen getting undressed in her apartment in a scene that is interspersed with a scene of Jake and Fitz discussing her as they have her under surveillance, which shows her resistance to their potential dominance of her, but also reminds the viewer that there are two other men in love with her while she is seducing a third.

In the 70s, it was considered shocking that the eponymous heroine of the Mary Tyler Moore Show (CBS, 1970-1977) - a series remarkable at that time for featuring a single 30something career woman, and a pioneer in the genre - possessed a double bed, even though she never appears with a man it. In The Good Wife episode Mind's Eye [06x14], an episode that features Alicia's inner thoughts, she imagines (and the viewer sees) herself alternately making love to Will, Johnny Elfman and fellow lawyer Finn Polmar. In the Scandal episode Where the Sun Don't Shine [04x09], Olivia replies to Jake's declaration of love by telling him that she desires both him and the President, but that she will choose herself saying, "I'm not choosing Jake. I'm not choosing Fitz. I'm choosing me. I'm choosing Olivia. And right now, Olivia is dancing. Now, you can dance with me or you can get off my dance floor. I'm fine dancing alone ». Both series thus represent a new negotiation of gender relations, where the heroine, the person positioned as "good", can be sexually interested in more than one man at the same time, and sexual relations and politics in the series go far beyond the traditional man/woman binary.

\section{Bad men, « old » men, and patriarchal hegemony...}

In her study of Buffy the Vampire Slayer (WB/UPN, 1997-2004), Lorna Jowett defines televised masculinity representations as either « old» or «new ». As she explains, «In simple terms old masculinity is macho, violent, strong and monstrous, while new masculinity is 'feminized,' passive, emotional, weak and human » (Jowett, 2005 : 95). Jowett underlines that "'good' new masculinity contrasts with 'bad' tough-guy masculinity by being 'feminized,' passive, sensitive, weak and emotional, and this contrast is partly about the separation of gender and behavior in new men " (Jowett, 
2005: 119). Yet she also considers that contemporary representations are complex and that male characters can have aspects of both.

Lotz also feels that televised gender representations are multifaceted. She maintains that « a spectrum of masculinities exists on US television » between the two extremes of «patriarchal masculinities" and «feminist masculinities» (Lotz, 2014:35). She writes, "This process of contesting patriarchal masculinities yields masculinities 'reconstructed' by feminism, so that a series might inhabit many 'degrees' of reconstruction that exist on a spectrum of masculinities " (Lotz, 2014:35-36). She uses the word '" hegemonic' to indicate deployment of masculinities that are presented as 'natural' and that received support within that narrative as acceptable or preferred" (Lotz, $2014: 40$ ). She notes that the "conceptualization of hegemonic masculinities " can be "fluid and shifting» and that sometimes «the hegemonic masculinities in a series align with patriarchal masculinities; however, many aspects of patriarchal masculinities are no longer hegemonic » (Lotz, $2014: 40$ ).

While men on both Scandal and The Good Wife exhibit a number of "new " and " old " versions of masculinity, the most important men in the lead heroines' lives tend towards the "old", or the "patriarchal», which is the "hegemonic " form of masculinity in the series. Peter Florrick is «old» or "patriarchal» masculinity personified: $\mathrm{He}$ is a politician, a leader, a father, promiscuous, and of dubious moral character. President Fitzgerald Grant is not only a leader, a father, and promiscuous, but he is also a murderer (both intentionally and unintentionally) ${ }^{8}$. Both men, despite being married, are more interested in their careers than in their children, and neither is particularly involved in childcare. Fitz represents «the crisis of masculinity " to some extent as he dreams of getting divorced, giving up his power and moving with Olivia to Vermont to have a "normal» life. Peter is more unrepentantly patriarchal, and becomes more ambitious as the series goes on. In season 7 , he even runs for president.

Both the heroines' secondary love interests also lean more towards the patriarchal version of masculinity. Olivia's secondary love interest, Jake Ballard eventually runs the secret spy organization B613 before finally becoming head of the National Security Agency (NSA). He was originally sent to spy on Olivia by both the President, his former friend, and by B613, but he stopped when he fell in love her. Alicia, while married to Peter, is in love with her boss, Will Gardner, the head of her law firm who loves sports and often seems more interested in success and winning cases than being a good person (he is killed off in season 5 to be somewhat replaced as a romantic interest by the lawyer Finn Polmar, who - while tall, dark and handsome, and gentler than the other romantic leads - is «neutered» in the sense that the heroine shows very little romantic interest in him, even if a certain tension exists between them). While not particularly "good", these male characters with shady personalities are also the key to the heroines' wielding of power. Thus, on the surface, there is a perceived valorization of the patriarch - the dominating male, the leader - who is neither particularly sweet nor kind.

This seeming reconciliation, even complicity, with patriarchal masculinity is not prevalent in all women-centered series featuring empowered female leads. For example, the innovation of Scandal's and The Good Wife's predecessors, the womencentered series featuring the iconic Girl Power heroines of the late 90s-early 2000s, was the disempowerment of hegemonic patriarchal masculinity: Strong, dominating male 
characters were not well received and did not meet a good end. In order to be with the heroines, they had to be good. Patriarchal males were often ultimately completely rejected by the heroines or killed off (or killed by them). As Lotz notes of these representations that "male characters" that were "exhibiting physical power and control, achieving occupational success as valued by capitalism, controlling a family as a patriarch, manifesting characteristics of the frontiersman, and displaying heterosexual power» were "most often villains» (Lotz, 2006: 78). Third-wave feminism ideology on television often underlines importance of cooperating with men and the undesirability of misandry. Beeler notes of the Girl Power series Charmed that it tried to distinguish itself from " the stereotype of second-wave feminism as anti-male " and inscribes itself in "the third wave's acceptance of having men become part of feminist work » (Beeler, 2007: 108-109). However, contrary to the Girl Power series, in Scandal and The Good Wife, the heroines cooperate and collaborate with men even when the men in question are exhibiting masculinity that is more patriarchal than feminist.

In Scandal and The Good Wife, there seems to be a reward for the heroines' support of patriarchs : power. When Alicia Florrick enters the workforce as a middle-aged woman who spent over a decade as a housewife, she only gets a job because of Will, yet it is clear that the Florrick name makes her no average first-year associate and gives her access to people and information that others would not possess. When Peter's campaign manager, Eli Gold, joins Alicia's law firm, his presence means that Alicia is afforded a bigger office. When she begins her own firm, her influence with her husband the governor contributes to her winning the Chumhum account needed to raise the necessary capital. Olivia's connection to Fitz and the White House not only gives her access to important people and information, but also allows her to influence and give input on important political decisions and situations, including both domestic and international affairs. Women are seen to benefit politically from their connection to patriarchal men: Mellie and Alicia both run for political office on the strength of their husband's power. Mellie runs successfully for senator and hopes to be president and Alicia runs for State's Attorney but has to withdraw once she has won due to political scandal. Yet both Fitz and Peter have difficulty at times supporting their wives' political aspirations.

No matter how problematic being with patriarchal men is for the heroines, these men are also framed as being charming and seductive. Even when Alicia is on the outs with Peter, she has an enduring attraction for him, which can be evidenced even in later seasons, like when he comforts and consoles her over wine on her loss of the State's Attorney position in The Deconstruction [06×20] - or even when they drink wine and discuss divorce on Alicia's bed in her bedroom in The Party [07x20] - and Olivia keeps going back to Fitz. In the episode Open Source [06x15], Alicia says to her patriarchal nemesis, fellow lawyer Louis Canning, «I seem to have some bad boy issues ». The " bad boys " (or patriarchal males) seem to be a complication for both Alicia and Olivia, yet these feminist heroines are attracted to both the patriarchal males and the power they yield, and seem to be co-dependent, or perhaps interdependent. The difference between the heroines' positions is that Alicia is the married woman, who «stands by her man » despite his various scandals and infidelities, while Olivia is the President's mistress, who supports him despite his many flaws.

The married couples - Mellie and Fitz, and Alicia and Peter - are at times truly together and at other times at odds. Alicia and Peter never divorce despite having discussions 
about it, and Alicia is shown in the last episode of the series supporting Peter at a press conference, but Fitz and Mellie finally do divorce in season 5, after many years of faking a happy marriage for the voting public. The Good Wife and Scandal thus expose the nature of both politics and gender as performance. To get elected, a politician must have sound family values, and a have a happy heteronormative family life. Gender binaries are deliberately exaggerated and reinforced to produce the perfect photo op of the pretty, smiling, wife, adoringly supporting her handsome manly husband. Yet behind the scenes, the picture is very different.

\section{Gender Reverse and Reboot : Gender Politics Renegotiated}

While Scandal and The Good Wife feature the desirability of patriarchal men and their power, it is interesting to explore who actually holds the power. There is a certain hypocrisy inherent in the perfect patriarchal male politician, and the perfect heterosexual couple, as displayed to the media to manipulate the voting public, a spectacle of masculinity and femininity that is pure performance rather than reality. While the patriarchal male is hegemonic in the series, and he is depicted as the political and even romantic ideal, does he truly hold the power?

In fact, the true power behind Peter and Fitz are Eli Gold and Cyrus Beene respectively. Both men are responsible for their candidates' being elected and maintaining their power. And both represent gay masculinity. The character of Cyrus is gay in the series, while the character of Eli is played by an actor (Alan Cumming) who is openly gay, something the public is likely aware of. Lotz notes of Barney from How I Met Your Mother (CBS, 2005-2014) that the " audience's probable extratextual knowledge of » the actor " as an out gay man » led to a certain awareness of the performance aspect of the depiction of patriarchal masculinity (Lotz, $2014: 1$ ).

ect hegemonic patriarchal masculinity as portrayed on the series is a construct, even within the series themselves. Moreover, power relations and power dynamics are complex: the men are often portrayed as victims, a traditionally «feminine » role and need to be saved by the women. In the case of Fitz and Peter, Olivia and Alicia bail them out of trouble, notably the scandals caused by their affairs. While the men spend more time in the spotlight, it is the women who keep them there, by repairing damage done to their image, fixing their problems, and campaigning for them.

The heroines come to the rescue of the secondary male characters as well. In The Good Wife, Alicia aids Finn when he is harassed and pursued by the State's Attorney James Castro. Her friend and associate Carey Agos is put in prison and his life is threatened. In the case of Scandal's Olivia, she has two violent men who are also victims in her care: Her lover Jake and her friend and associate Huck, both of whom were damaged by their association with B613, which recruits men who are vulnerable because they have very little or uncaring family, and not much to live for, and turns them into killing machines by torturing, threatening and/or manipulating them into compliance. Jake, although violent and morally ambiguous (when he first meets Olivia, he acts like a stalker as he films her in her home to surveil her for the patriarchal forces of both B613 and the President), he becomes a sympathetic character when he falls in love with her. Despite his extreme violence, which is a characteristic traditionally associated with 
masculinity, he is in a way the most feminized, as he is positioned as a victim, and freely expresses his need to love Olivia and for her to love him. He is often topless and thus a sex object (which is traditionally the women's position), and his love renders him in a way quite vulnerable. He is often shown as being devoted to helping Olivia and supporting her, and thus despite his being a soldier, and patriarchal, he is a not quite a «traditional » man. On the spectrum of feminist or patriarchal masculinities, his is a representation of some contestation to patriarchal masculinity. He was psychologically tortured by the patriarchal organization B613 (run by Olivia's father Eli Pope, who considers him to be a «son»), and forced to live underground in the "hole " as punishment. In season 4 , he unsuccessfully tries to take down the organization that disempowered him and in season 5, even though he is in charge of the NSA, he still finds it difficult to escape Eli Pope's control. The viewer learns that their bond was forged when Eli encouraged him to kill his abusive father, so even though Jake becomes technically quite powerful, he is still positioned as a victim.

As for Alicia's boss Will in The Good Wife, as the head of a law firm and a man who is very aggressive in business, he is positioned as a patriarchal male. He is also a victim at one point when Alicia's jealous husband Peter has him investigated for corruption, which leads to his being temporarily disallowed from practicing law. He is quite patriarchal in his habits, a relatively "manly man", who plays basketball, and is a strongly heterosexual confirmed bachelor. He is into casual affairs with little feeling behind them, yet he does respect women, especially his partner, Diane. His fatal flaw that makes him vulnerable is Alicia. His affection for her causes him problems at his law firm as well as problems with Alicia's more powerful husband, Peter. While Alicia and Will seem to have feelings for each other throughout the seasons in which he appears, their actual affair is short-lived and Alicia reconciles with Peter soon after it. When Alicia starts her own firm behind his back, he becomes aggressive and antagonistic towards her in the courtroom, and is eventually killed in a courtroom shooting.

Neither Jake nor Will is a "new man » but their support and love of feminist heroines, their disempowerment by and resistance to patriarchal forces, and the fact that their love makes them vulnerable, positions them more towards "feminist masculinities " than "patriarchal masculinities » and illustrates the intricacy of contemporary gender representations. The heroines - Olivia, who "wears the white hat", and "Saint Alicia » - are often portrayed as saviors of the male characters, even if they are also themselves the victims at times.

As evidenced by the twists in the last completed seasons of The Good Wife and Scandal to date, romantic relationships and power dynamics are complex on the series, and patriarchal men and patriarchal masculinities continue to be important. Alicia's « thing for bad boys» leads her to sleep with her campaign manager Johnny over the «nice man » Finn. In season 7, she carries on an affair with her firm's tall, dark, handsome investigator, Jason, who is slightly shady a bit of a mystery, yet despite this, at the end of the series, she is still married to Peter (which she says is to support him through one last scandal). Olivia, while technically single, still seems to have feelings for both Jake and the President. The Alpha patriarchal male seems to be more important to the heroine than the others, yet the heroines do not live with them. Alicia keeps her own apartment, both when she is reconciled with Peter and when she is not. Olivia has thus far refused to run off with Fitz to Vermont, even though he has offered to give up everything to do so. While she moves in with him for a short time in the White House in 
season 5 , she cannot tolerate the lack of freedom that comes with being in the role of " First Lady " (even though they do not marry), so she moves out. This illustrates pushpull of patriarchal and feminist discourses at play. The heroines are ambitious: Their power is increased, and their ambitions are furthered, by their association with powerful men, whom they often desire, and yet to whom they do not fully submit.

\section{Conclusion}

Men's and women's identities are being negotiated both on and off the screen, following in the wake of feminist successes such as its becoming "normal» and accepted for women to work outside the home and to love whom and how they wish. Books like Hanna Rosin's The End of Men and Maureen Dowd's Are Men Really Necessary? raise the issue of the end of male dominance and importance (Rosin, 2012 ; Dowd, 2006), but « the end of men » is not yet neigh. Lotz notes, « Much evidence makes it clear that Western societies remain characterized by patriarchal dominance, but it also evident that the work of second-wave feminists notably and significantly changed these societies, in particular by opening many public spaces to women and adjusting prevailing notions of their roles» (Lotz, 2014: 25). Even if the economic and commercial imperatives of primetime television mean that TV series' producers, in order to attract viewers/consumers, might maintain and favor certain aspects of traditional masculinity and femininity (like handsome men and beautiful women), TV series like The Good Wife and Scandal also represent sites of resistance to potential patriarchal dominance. From the non-exhaustive examples that were given in this article, it can be seen that these series take on and expose the feminist issues of wage inequality, work-life balance, opt-out moms, unfair treatment of women in politics, and "slut shaming ». This positions the series as carrying out the work of the second wave and boldly contesting patriarchy, even while showing the heroines as literally being in bed with patriarchal males whom they genuinely love, even if they also do seem at times to be a means to an end.

For future research, a more complete reception study to see how these representations are received would be useful to more deeply examine the interplay between institutions, discourses and potential viewer resistance. The Good Wife has finished, leaving the narrative open-ended, with many unanswered questions about Alicia's future, but a spin-off called The Good Fight is planned featuring her partner Diane Lockhart that promises some narrative closure for Alicia who may even guest star (Harnick, June and December 2016). When Scandal and this spin-off take their final bows, it would also be interesting to examine how the series' narratives ultimately end: Will the heroines suffer "backlash »- an ultimate smackdown from the patriarchy like the many strong heroines that Sara Crosby notes were killed off in the 2000-2001 TV season (Crosby, 2004), or will they remain successful and strong, and finally be liberated from the hegemony of patriarchal masculinity? 


\section{BIBLIOGRAPHY}

BARR Merril (2015), « 'The Blacklist' vs ‘Scandal' Ratings Hurt 'Backstrom' Now, May Help Later », Forbes, February 6 [Online] : http://www.forbes.com/sites/merrillbarr/2015/02/06/the-blacklistscandal-ratings/\#6240e40d7a28 [Consulted: December 28, 2016].

BEELER Karin (2007), « Old Myths, New Powers: Images of Second-wave and Third-wave Feminism in Charmed », in Karin BEELER and Stan BEELER (eds.), Investigating Charmed: The Magic Power of TV, London, I.B. Tauris, p. 101-111.

BREGER Esther (2014), « A Mid-Season Assessment of 'Scandal's' New Feminist Speechifying », New Republic, November 19. [Online] : http://www.newrepublic.com/article/120344/scandals-seasonfour-feminist-speechifiying [Consulted September 28, 2015].

BRUNDSON Charlotte, Julie D'ACCI and Lynn SPIGEL (eds.) (1997) Feminist Television Criticism : A Reader, Oxford, Clarenden Press.

CROSBY Sara (2004), «The Cruelest Season : Female Heroes Snapped into Sacrificial Heroines », in Sherrie A. INNESS (ed.), Action Chicks : New Images of Tough Women in Popular Culture, New York, Palgrave Macmillan, p. 153-178.

D'ACCI Julie (1994), Defining Women: Television and the Case of Cagney and Lacey, Chapel Hill, The University of North Carolina Press.

DOCKTERMAN Eliana (2013), « TV’s Strongest Female Characters Share One Stupid Flaw », Time Magazine, October 10. [Online] : http://entertainment.time.com/2013/10/10/tvs-strongestfemale-characters-share-one-stupid-flaw/ [Consulted on September 27, 2015].

DowD Maureen (2006), Are Men Necessary? : When Sexes Collide, New York, Berkley.

DRUMMING Neil (2014), « Lean out: The underhanded feminism of 'The Good Wife'" , Salon, May 18. [Online]: http://www.salon.com/ 2014/05/18/

lean_out_the_underhanded_feminism_of_the_good_wife/ [Consulted September 28, 2015].

FOUCAULT Michel [1990(1978)], The History of Sexuality, Volume 1: An Introduction, Trans. Robert Hurley, New York, Random House.

GIBSON Megan (2014), « Here's a Sliver of Good News About Women in Television », Time Magazine, September 16. [Online]: http://time.com/3386285/women-television-boxed-in-study/ [Consulted September 28, 2015].

HAITMAN Diane (2012), « EMMYS : 'The Good Wife' Creators Robert \& Michelle King », Deadline, June 2, [Online]: http://deadline.com/2012/06/emmys-the-good-wife-creators-aim-to-remaintrue-to-their-characters-281144/ [Consulted December 28, 2016].

HARNICK Chris (2016), « Everything You Need to Know About The Good Wife Spinoff, The Good Fight », E! Online, December 16. [Online]: http://www.eonline.com/news/802360 everything-you-need-toknow-about-the-good-wife-spinoff. [Consulted December 28, 2016].

HARNICK Chris (2016), «The Good Wife Spinoff Scoop : Alicia Florrick Closure, New Faces and More », E! Online, June 6. [Online]: http://www.eonline.com/news/770428/the-good-wife-spinoffscoop-alicia-florrick-closure-new-faces-and-more [Consulted June 29, 2016]. 
HARNICK Chris (2012), «'The Good Wife' : Backlash Over Kalinda And Nick Storyline Prompts Early Ending », Huffington Post, December 26. [Online]: http://www.huffingtonpost.com/2012/10/26/ the-good-wife-backlash-kalinda- husband-story_n_2026014.html [Consulted September 28, 2015]. HENRY Astrid (2006), «Orgasms and Empowerment : Sex and the City and the third wave feminism ", in Kim AKASS and Janet MCCABE (eds.), Reading "Sex and the City ", London, I.B. Tauris, p. 65-82.

HOLMLUND Chris (1993), « Masculinity as Multiple Masquerade: The 'mature' Stallone and the Stallone clone », in Steven COHAN and Ina RAE HARK (eds.), Screening the Male: Exploring Masculinities in Hollywood Cinema, London, Routledge, p. 213-229.

INNESS Sherrie A. (1996), The Lesbian Menace: Ideology, Identity, and the Representation of Lesbian Life, Amherst, University of Massachusetts Press.

JOWETT Lorna (2005), Sex and the Slayer : A Gender Studies Primer for the Buffy Fan, Middletown, Wesleyan University Press.

LAUZEN Martha M. (2014), « Boxed In : Employment of Behind-the-Scenes and On-Screen Women in 2013-14 Prime-time Television », Boxed In, Center for the Study of Women in Television and Film, San Diego State University, 2014. [Online]: https://pmcdeadline2.files.wordpress.com/ 2014/09/2013-14-boxed-in-report-12.pdf [Consulted September 28, 2015].

KESSLER Glenn (2014), « President Obama's persistent '77-cent' claim on the wage gap gets a new Pinocchio rating », The Washington Post, April 9 [Online]: https://www.washingtonpost.com/ news/fact-checker/wp/2014/04/09/president-obamas-persistent-77-cent-claim-on-the-wagegap-gets-a-new-pinocchio-rating/?utm_term=.06215d6997c3 [Consulted December 28, 2016]. KISSELL Rick (2015), « 'Scandal,' ‘The Walking Dead' Have the Most Socially Loyal Fans, Nielsen Report Says », Variety, August 25. [Online]: http://variety.com/2015/data/news/scandal-thewalking-dead-most-socially-loyal-fans-1201576823/ [Consulted September 28, 2015].

LEE Ashley (2016), « Shonda Rhimes Stresses Importance of Diverse TV in Trump Era: 'My Pen Has Power' ", The Hollywood Reporter, November 21. [Online]: http://www.hollywoodreporter.com/ news/shonda-rhimes-stresses-diverse-tv-trump-era-international-emmys-2016

LOCKER Melissa (2015) « 'We're all news junkies' : why The Good Wife writing team is one of TV's sharpest », The Guardian, May 21 [Online]: http://www.theguardian.com/tv-and -radio/2015/ may/21/news-junkies-good-wife-writing-team-is-one-of-the-sharpest-in-tv [Consulted September 29, 2015].

LOTZ Amanda D. (2014), Cable Guys : Television and Masculinities in the 21st Century, New York, NYU press.

LOTZ Amanda D. (2006), Redesigning Women : Television after the Network Era, Urbana, University of Illinois Press.

MILLER Catriona (2007) «'I Just Want to Be Normal Again': Power and Gender in Charmed », in Karin BEELER and Stan BEELER (eds.), Investigating Charmed: The Magic Power of TV, London, I.B. Tauris, p. 67-78.NPR STAFF (2015), « Meet The Power Couple Behind 'The Good Wife' «, NPR, May 6. [Online]: http://www.npr.org/2015/05/06/404209225/the-husband-and-wife-power-couplebehind-cbss-the-good-wife [Consulted September 28, 2015].

POKEDOFF Lauren (2014), « 9 Of The Most Powerful Feminist Characters Currently On TV », Buzzfeed, August 9. [Online]: http://www.buzzfeed.com/laurenpokedoff/ 9-most-powerfulfeminist-characters-currently-on-t-a31h\#.xxoaPeAEvo [Consulted September 28, 2015]. 
PRINCE Richard (2014), « What It Means That Scandal Is Sizzling Hot Among Black Women », The Root, January 9 [Online]: http://www.theroot.com/blog/journal-isms/ abc_drama_scandal_is_popular_among_black_women/ [Consulted: December 28, 2016]. PUTNAM Lindsay (2014), « Is 'Scandal' the most feminist show on TV? », New York Post, October 31. [Online]: http://nypost.com/2014/10/31/is-scandal-the-most-feminist-show-on-tv/ [Consulted: September 29, 2015].

Rosin Hanna (2012), The End of Men : And the Rise of Women, New York, Riverhead.

SAMAKOW Jessica (2015), « Olivia Pope's Abortion Got 1 Minute Of Airtime - And That's All It Needed », The Huffington Post, November 20 [Online]: http://www.huffingtonpost.com/entry/ olivia-popes-abortion-got-1-minute-of-airtime-and-thats-all-

itneeded_us_564e97c6e4b0879a5b0a6cc0 [Consulted September 29, 2015].

SIMPSON Cynn (2012), «Judy Smith, the inspiration for Scandal's Olivia Pope, interviewed by Cynn Simpson », WJLA, April 6 [Online]: http://wjla.com/news/entertainment/judysmith-theinspiration-for-scandal-s-olivia-pope-interviewed-by-cynn-simpson-74627 [Consulted September $29,2015]$.

TASKER Yvonne and Diane NEGRA (2007), « Feminist Politics and Postfeminist Culture », in Yvonne TASKER and Diane NEGRA (eds.), Interrogating Postfemism : Gender and the Politics of Popular Culture, Durham, Duke University Press, p. 1-25.

THIELMAN Sam (2014), « What Women Watch on TV: Their viewing habits may surprise you », Adweek, March 31. [Online]: http://www.adweek.com/news/television/what-women-watchtv-156621?page=1 [ Consulted December 27, 2016].

VEGA Tanzina (2013), « A Show Makes Friends and History, 'Scandal' on ABC Is Breaking Barriers », The New York Times, January 16. [Online]: http://www.nytimes.com/2013/01/17/arts/ television/scandal-on-abc-is-breaking-barriers.html [Consulted December 27, 2016].

\section{Websites}

http://womenintvfilm.sdsu.edu

www.imdb.com

www.redditt.com

www.twitter.com

www.wikipedia.org

\section{NOTES}

1. In addition to the news articles cited in this section, other sources for basic production information include: www.imdb.com, www.wikipedia.org; www.deadline.com [Consulted June $29,2016]$

2. The full report can be found at https://pmcdeadline2.files.wordpress.com/2014/09/2013-14boxed-in-report-12.pdf [Consulted September 24, 2015]. For more information about gender equality in TV production, see the website of Center for the Study of Women Television \& Film maintained by San Diego State University at http://womenintvfilm.sdsu.edu [Consulted June 29, 2016].

3. For a complete list of awards, see www.imdb.com [Consulted September 24, 2015]. 
4. See for example, Melissa Locker, “'We're all news junkies': why The Good Wife writing team is one of TV's sharpest », The Guardian, May 21, 2015 [Online]: http://www.theguardian.com/tvand-radio/2015/may/21/news-junkies-good-wife-writing-team-is-one-of-the-sharpest-in-tv [Consulted September 29, 2015].

5. Complete thread available at https://www.reddit.com/r/thegoodwife/ comments/4hv1q3/ a_fond_feminist_farewell_to_ms_florrick/? and https://www.reddit.com/r/Scandal/comments/ 3tke4q/misogyny_disguised_as_feminism/? [Consulted December 28, 2016 Consulted December $28,2016]$.

6. To see the campaign, see https://twitter.com/Scandal_Fansite/status/628450581334495232? lang=en, [Consulted December 28, 2016].

7. I argue here that Will is a secondary love interest because even though Alicia is understood to have feelings for him, and he is a more important character than Peter, their actual affair is very brief, whereas Alicia is much more engaged and committed to actually having a relationship with Peter.

8. He notably kills an elderly female Supreme Court judge with his bare hands before she can reveal a scandal about him, and starts a war in East Sudan to save Olivia.

\section{ABSTRACTS}

This paper explores the representation of gender in The Good Wife and Scandal, two American primetime television series, which, pursuant to feminist gains, showcase heroines who are very intelligent and powerful. These series are a site of negotiation between discourses that valorize certain aspects of patriarchal masculinity- notably the power, social success and sex appeal of the patriarchal man -and oppositional feminist discourses.

Cet article propose d'étudier la représentation de genre dans The Good Wife et Scandal, deux séries télévisées américaines diffusées à une heure de grande écoute qui, suite aux avancées du mouvement féministe, mettent en valeur des héroïnes intelligentes et puissantes. Ces séries sont un site de négociation entre des discours qui valorisent certains attributs de la masculinité patriarcale - notamment le pouvoir, le succès social et l'attrait sexuel de l'homme patriarcal - et des discours féministes contestataires.

\section{INDEX}

Keywords: masculinity, femininity, feminism, TV series, power, media studies

Mots-clés: masculinité, féminité, féminisme, séries télévisées, études médiatiques 